\title{
ASSESSMENT OF ECONOMIC SUSTAINABILITY OF AN ENTERPRISE
}

\author{
M. Thierling ${ }^{1}$, V.G. Pluzhnikov ${ }^{2}$ \\ ${ }^{1}$ Ludwig-Geissler-School, Hanau, Germany \\ ${ }^{2}$ South Ural State University, Chelyabinsk, Russian Federation \\ E-mails: manfreg@thierling-hanau.de,pvg@susu.ru
}

In a turbulent economy and increasing economic crises, the question of assessing the economic sustainability of a corporation is quite relevant and in demand in scientific research. At the same time, with a certain degree of conditionality, all works in this direction can be divided into two clusters: works based on traditional indicators of financial stability and ones using original scientific approaches to determining the economic condition of an enterprise. This article belongs to the works of the second cluster. The basis for assessing the economic sustainability of an enterprise is the economic and mathematical modelling of the operating activities of the enterprise based on the well-known Cobb - Douglas production function. A methodology is developed for constructing a mathematical model of the enterprise's activity, for determining elasticity indicators of output according to the resources used in the production process and elasticity of production, on the basis of the dynamics of which an approach to assessing economic stability is proposed. The methodology was tested on the data of PJSC Chelyabinsk Tube Rolling Plant during the implementation of the innovation project "Height 239 ".

Keywords: mathematical modelling; economic sustainability; company; production function.

\section{Introduction}

In a turbulent economy and increasing economic crises, the question of assessing the economic stability of a corporation is quite relevant and in demand in scientific research [1-5]. At the same time, with a certain degree of conditionality, all works in this direction can be divided into two clusters: works based on traditional indicators of financial stability and ones using original scientific approaches to determining the economic condition of an enterprise. In this article, the assessment of the economic sustainability of an enterprise is based on mathematical modelling of the enterprise's operations based on a production function.

\section{Research Methodology}

To assess the economic sustainability of an enterprise, it is proposed to use the economic-mathematical model of the operating activity of the enterprise. The algorithm for constructing mathematical models of the enterprise's operations is based on the use of the production function

$$
C P=A \cdot N^{\alpha} \cdot F A^{\beta} \cdot C A^{\gamma} \cdot e^{\lambda t},
$$

where $C P$ represents the commercial products, thousand rubles / year; $N$ is the number of staff, people; $F A$ is the volume of fixed assets, thousand rubles; $C A$ is the current assets, thousand rubles / year; $A$ is the empirically determined coefficient that provides conjugation of the dimension of the left and right sides of equation (1) and at the same time 
performs the role of a large-scale translation factor between all components of formula (1); $\alpha, \beta, \gamma$ are the elasticity coefficients of output according to the corresponding resource, dimensionless; $e$ is base of the natural logarithm; $\lambda$ is the coefficient of elasticity that shows the effect of "autonomous" technical progress on production results, dimensionless; $t$ is the time normalized relative to the base year, years, $\left(t_{i}=T_{i}-T_{b}\right)$.

In the most general form, the parameters $A, \alpha, \beta, \gamma$ of production function (1) are based on retrospective data on $C P, N, F A, C A$, $t$, as a solution to the system of linear equations

$$
\left\{\begin{array}{l}
\sum_{i=1}^{m} \ln C P_{i}=m \cdot \ln A+\alpha \cdot \sum_{i=1}^{m} \ln N_{i}+\beta \cdot \sum_{i=1}^{m} F A_{i}+\gamma \cdot \sum_{i=1}^{m} \ln C A_{i}+ \\
+\lambda \cdot \sum_{i=1}^{m} t_{i}, \\
\sum_{i=1}^{m}\left(\ln C P_{i} \cdot \ln N_{i}\right)=\ln A \cdot \sum_{i=1}^{m} \ln N_{i}+\alpha \cdot \sum_{i=1}^{m}\left(\ln N_{i}\right)^{2}+ \\
+\beta \cdot \sum_{i=1}^{m}\left(\ln F A_{i} \cdot \ln N_{i}\right)+\gamma \cdot \sum_{i=1}^{m}\left(\ln C A_{i} \cdot \ln N_{i}\right)+\lambda \cdot \sum_{i=1}^{m}\left(t_{i} \cdot \ln N_{i}\right), \\
\sum_{i=1}^{m}\left(\ln C P_{i} \cdot \ln F A_{i}\right)=\ln A \cdot \sum_{i=1}^{m} \ln F A_{i}+\alpha \cdot \sum_{i=1}^{m}\left(\ln F A_{i} \cdot \ln N_{i}\right)+ \\
+\beta \cdot \sum_{i=1}^{m}\left(\ln F A_{i}\right)^{2}+\gamma \cdot \sum_{i=1}^{m}\left(\ln F A_{i} \cdot \ln C A_{i}\right)+\lambda \cdot \sum_{i=1}^{m}\left(t_{i} \cdot \ln F A_{i}\right), \\
\sum_{i=1}^{m}\left(\ln C P_{i} \cdot \ln C A_{i}\right)=\ln A \cdot \sum_{i=1}^{m} \ln C A_{i}+\alpha \cdot \sum_{i=1}^{m}\left(\ln C A_{i} \cdot \ln N_{i}\right)+ \\
+\beta \cdot \sum_{i=1}^{m}\left(\ln C A_{i} \cdot \ln F A_{i}\right)+\gamma \cdot \sum_{i=1}^{m}\left(\ln C A_{i}\right)^{2}+\lambda \cdot \sum_{i=1}^{m}\left(t_{i} \cdot \ln C A_{i}\right), \\
\sum_{i=1}^{m}\left(\ln C P_{i} \cdot t_{i}\right)=\ln A \cdot \sum_{i=1}^{m} t_{i}+\alpha \cdot \sum_{i=1}^{m}\left(t_{i} \cdot \ln N_{i}\right)+ \\
+\beta \cdot \sum_{i=1}^{m}\left(t_{i} \cdot \ln F A_{i}\right)+\gamma \cdot \sum_{i=1}^{m}\left(t_{i} \cdot \ln C A_{i}\right)+\lambda \cdot \sum_{i=1}^{m}\left(t_{i}\right)^{2},
\end{array}\right.
$$

where $m$ is the number of years for which retrospective data are collected $(m>4)$.

Sometime system of equations (1) may not have a solution. In this case, there is a phenomenon that Mendershausen called the effect of multicollinearity between independent variables. To overcome this barrier, the following transformations must be made.

Divide the total differential of function (1) by the function itself and get

$$
d C P / C P=\alpha \cdot d N / N+\beta \cdot d F A / F A+\gamma \cdot d C A / C A+\lambda \cdot d t .
$$

Denote

$$
\begin{gathered}
\frac{d C P}{C P}=2 \cdot \frac{C P_{i+1}-C P_{i}}{C P_{i+1}+C P_{i}}=z, \frac{d N}{N}=2 \cdot \frac{N_{i+1}-N_{i}}{N_{i+1}+N_{i}}=x, d t=t_{i+1}-t_{i}=1, \\
\frac{d F A}{F A}=2 \cdot \frac{F A_{i+1}-F A_{i}}{F A_{i+1}+F A_{i}}=y, \frac{d C A}{C A}=2 \cdot \frac{C A_{i+1}-C A_{i}}{C A_{i+1}+C A_{i}}=w .
\end{gathered}
$$

Then expression (3) takes the form

$$
z=\alpha \cdot x+\beta \cdot y+\gamma \cdot w+\lambda .
$$


Based on the transformed initial data from system of equations (5), we find the elasticity coefficients $\alpha, \beta, \gamma, \lambda$.

$$
\left\{\begin{array}{l}
\sum_{i=1}^{m} z_{i}=\lambda \cdot m+\alpha \cdot \sum_{i=1}^{m} x_{i}+\beta \cdot \sum_{i=1}^{m} y_{i}+\gamma \cdot \sum_{i=1}^{m} w_{i} \\
\sum_{i=1}^{m}\left(x_{i} \cdot z_{i}\right)=\lambda \cdot \sum_{i=1}^{m} x_{i}+\alpha \cdot \sum_{i=1}^{m}\left(x_{i}\right)^{2}+\beta \cdot \sum_{i=1}^{m}\left(x_{i} \cdot y_{i}\right)+ \\
+\gamma \cdot \sum_{i=1}^{m}\left(x_{i} \cdot w_{i}\right), \\
\sum_{i=1}^{m}\left(y_{i} \cdot z_{i}\right)=\lambda \cdot \sum_{i=1}^{m}\left(t_{i} \cdot y_{i}\right)+\alpha \cdot \sum_{i=1}^{m}\left(x_{i} \cdot y_{i}\right)+\beta \cdot \sum_{i=1}^{m}\left(y_{i}\right)^{2}+ \\
+\gamma \cdot \sum_{i=1}^{m}\left(y_{i} \cdot w_{i}\right), \\
\sum_{i=1}^{m}\left(w_{i} \cdot z_{i}\right)=\lambda \cdot \sum_{i=1}^{m}\left(w_{i}\right)+\alpha \cdot \sum_{i=1}^{m}\left(w_{i} \cdot x_{i}\right)+\beta \cdot \sum_{i=1}^{m}\left(y_{i} \cdot w_{i}\right)+ \\
+\gamma \cdot \sum_{i=1}^{m}\left(w_{i}\right)^{2} .
\end{array}\right.
$$

According to the found numerical values of the elasticity coefficients, the coefficient $A$ is as follows:

$$
A=\frac{\sum_{i=1}^{m} z_{i} \cdot x_{i}^{\alpha} \cdot y_{i}^{\beta} \cdot w_{i}^{\gamma} \cdot e^{\lambda t}}{\sum_{i=1}^{m}\left(x_{i}^{\alpha} \cdot y_{i}^{\beta} \cdot w_{i}^{\gamma} \cdot e^{\lambda t}\right)^{2}} .
$$

The parameters of production function (1) found by the presented algorithm are an economic-mathematical model of the operating activity of the enterprise. Its reliability is checked analytically by assessing the deviations of the actual values of the exogenous indicator in the retrospective section from the corresponding theoretical values. Assessing can be carried out according to well-known criteria of agreement: Fisher, Student, Kolmogorov-Smirnov and others used to test statistical hypotheses in conventional approximation models.

The indicator calculated during the simulation $h=\alpha+\beta+\gamma$ called the elasticity of production. Its value shows how the scale of production affects output. If $h=1$, then function (1) assumes a constant effect of growth in the scale of production. If $h>1$, the increasing effect of growth in production scales prevails, i.e. in this production process there is an increasing return on production resources. If $h<1$, a decreasing effect of growth in production scales is manifested, i.e. the company reduces the return of resources involved in production.

However, this indicator can be used to assess the economic sustainability of the enterprise. For this purpose, it is necessary to consider it in dynamics. If $\partial h / \partial t>0$, at $t=\overline{1, T}$, then there is economic stability of the enterprise, otherwise we talk about reducing the economic stability of the enterprise. The results of such an assessment can be used as KPI to stimulate top managers for the year. The methodology was tested on the data of PJSC Chelyabinsk Tube Rolling Plant during the implementation of the innovation project "Height 239".

We express our sincere gratitude to the Doctor of Economics, Professor Veniamin Gennadievich Mokhov, congratulate him on his seventieth birthday and wish him further scientific success. 


\title{
References
}

1. Schmidt A.V. Modern Methodological Approaches to the Assessment and Forecasting of Indicators of Economic Sustainability of Industrial Enterprises. Bulletin of the South Ural State University. Series: Economics and Management, 2010, vol. 14, no. 20, pp. 37-41.

2. Kolosova T.V. Ensuring the Sustainable Development of the Enterprise on the Basis of Increasing Its Innovative Potential: the Author's Abstract. PhD Thesis. Nizhny Novgorod, 2011.

3. Mokhov V.G. Methods of Marginal Analysis of Entrepreneurial Activity. Bulletin of the South Ural State University. Series: Economics and Management, 2012, vol. 21, no. 9, pp. 79-83. DOI: $10.1111 / \mathrm{j} .1530-9134.2011 .00328 . x$

4. Ugolnitsky G.A. Ustoychivoe razvitie organizatsiy. Sistemnyy analiz, matematicheskie modeli $i$ informatsionnye tekhnologii upravleniya [Sustainable Development of Organizations. Systems Analysis, Mathematical Models and Management Information Technologies]. Moscow, Izdatel'stvo fiziko-matematicheskoy literatury, 2011. (in Russian)

5. Bilchak V.S., Borodin A.I. Formirovanie ustoychivogo razvitiya predpriyatiya regiona: mekhanizmy, metody, upravlenie (ekologo-ekonomicheskiy aspekt) [Formation of Sustainable Development of an Enterprise in the Region: Mechanisms, Methods, Management (Ecological and Economic Aspect)]. Kaliningrad, Kant, 2009. (in Russian)

Received March 11, 2020

УДК 330.322.013+001.895

DOI: $10.14529 / \mathrm{mmp200310}$

\section{ОЦЕНКА ЭКОНОМИЧЕСКОЙ УСТОЙЧИВОСТИ ПРЕДПРИЯТИЯ}

\author{
М. Тирлине ${ }^{1}$, В.Г. Плужников ${ }^{2}$ \\ ${ }^{1}$ Школа Людвиг-Гесслер, г. Ханау, Германия \\ ${ }^{2}$ Южно-Уральский государственный университет, г. Челябинск, \\ Российская Федерация
}

В условиях турбулентной экономики и участившихся экономических кризисов вопрос оценки экономической устойчивости корпорации является достаточно актуальным и востребованным в научных исследованиях. При этом с определенной долей условности все работы в этом направлении можно подразделить на два кластера: основанные на традиционных показателях финансовой устойчивости и работы, использующие оригинальные научные подходы к определению экономического состояния предприятия. Данная статья относится к работам второго кластера. В основу оценки экономической устойчивости предприятия положено экономико-математическое моделирование операционной деятельности предприятия на основе широко известной производственной функции Кобба - Дугласа. Разработана методика построения математической модели деятельности предприятия, определения показателей эластичности выпуска продукции по используемым в процессе производства ресурсам и эластичности производства, на основе динамики которого предложен подход к оценке экономической устойчивости. Методика была апробирована на данных ПАО «Челябинский трубопрокатный завод», при реализации инновационного проекта «Высота $239 »$.

Ключевые слова: математическое моделирование; экономическая устойчивость; предприятие; производственная функиия. \& Computer Software (Bulletin SUSU MMCS), 2020, vol. 13, no. 3, pp. 93-97 


\section{Литература}

1. Шмидт, А.В. Современные методические подходы к оценке и прогнозированию показателей экономической устойчивости промышленных предприятий / А.В. Шмидт // Вестник ЮУрГУ. Серия: Экономика и менеджмент. - 2010. - № 20 (14). - С. 37-41.

2. Колосова, Т.В. Обеспечение устойчивого развития предприятия на основе повышения его инновационного потенциала: автореф. дис. д-ра экон. наук / Т.В. Колосова. - Нижний Новгород, 2011.

3. Мохов, В.Г. Методика маржинального анализа деятельности предпринимателя / В.Г. Мохов // Вестник ЮУрГУ. Серия: Экономика и менеджмент. - 2012. - № 9 (21). C. $79-83$.

4. Угольницкий, Г.А. Устойчивое развитие организаций. Системный анализ, математические модели и информационные технологии управления / Г.А. Угольницкий. - М.: Изд-во физико-математической литературы, 2011.

5. Бильчак, В.С. Формирование устойчивого развития предприятия региона: механизмы, методы, управление (эколого-экономический аспект) / В.С. Бильчак, А.И. Бородин. Калининград: Изд-во РГУ им. И. Канта, 2009.

Манфред Тирлинг, доктор естественных наук, школа Людвиг-Гесслер (г. Ханау, Германия), manfreg@thierling-hanau.de.

Владимир Германович Плужников, кафедра «Информационные технологии в экономике», Южно-Уральский государственный университет (г. Челябинск, Российская Федерация), pvg@susu.ru.

Поступила в редакиию 11 марта 2020 г. 